Abstracta Iranica Abstracta Iranica

Revue bibliographique pour le domaine irano-aryen

Volume 32-33 | 2013

Comptes rendus des publications de 2009-2010

\title{
F. Millar. Rome's 'Arab' Allies in Late Antiquity. Conceptions and Representations from within the Frontiers of the Empire
}

\section{Carlo Lippolis}

\section{(2) OpenEdition \\ 1 Journals}

Electronic version

URL: http://journals.openedition.org/abstractairanica/40554

DOI: $10.4000 / a b s t r a c t a i r a n i c a .40554$

ISSN: 1961-960X

Publisher:

CNRS (UMR 7528 Mondes iraniens et indiens), Éditions de l'IFRI

Printed version

Date of publication: 1 December 2013

ISSN: 0240-8910

Electronic reference

Carlo Lippolis, «F. Millar. Rome's 'Arab' Allies in Late Antiquity. Conceptions and Representations from within the Frontiers of the Empire », Abstracta Iranica [Online], Volume 32-33 | 2013, document 187, Online since 01 July 2016, connection on 04 October 2020. URL : http://journals.openedition.org/ abstractairanica/40554; DOI : https://doi.org/10.4000/abstractairanica.40554

This text was automatically generated on 4 October 2020.

Tous droits réservés 
F. Millar. Rome's 'Arab' Allies in Late Antiquity. Conceptions and Representations from within the Frontiers of the Empire

Carlo Lippolis 


\section{REFERENCES}

F. Millar. « Rome's ‘Arab’ Allies in Late Antiquity. Conceptions and Representations from within the Frontiers of the Empire ", in : H. Börm, J. Wiesehöfer, eds., Commutatio et Contentio. Studies in the Late Roman, Sasanian, and Early Islamic Near East in Memory of Zeev Rubin. Düsseldorf, 2010, p. 199-226.

1 This chapter outlines the information, or lack of it, on Arabia in literary sources from inside the Roman Empire's borders in late antiquity. Roman relations with peoples of the desert and/or steppes of Syria and the Arabian peninsula were central in the conflict/contact with the Sasanians. They are also important for understanding this frontier, the history of Christianity and the origins of Islam. This study explores the nature and limits of part of the available evidence from inside the Empire's borders between the middle of the fourth and the end of the sixth centuries. Despite the significant role played by "Arab allies" in the Roman Empire's history, "classical" authors did not show any interest for a systematic inquiry on Arabia and its peoples (tribes, origins, movements, settlements, family genealogies, etc.). The author explains that questions about origins, identities and social structure should be investigated by resorting to other sources: contemporary inscriptions from the peninsula, Syriac writings from the Sasanian Empire, Syriac post-Islamic narratives and Arabic accounts of events written in the eight century and afterwards.

\section{AUTHORS}

\section{CARLO LIPPOLIS}

Università di Torino 